\title{
Inhabitation as more-than-dwelling. Notes for a renewed grammar
}

\begin{abstract}
Bleak urban futures and the obscure perspective on housing calls for renewed attention across several disciplines, approaches and geographies. Michele Lancione (2019) recently pleaded to study 'radical housing' within everyday practices of dwelling for those living at the margins, where the latter are understood as the site where 'a politics of life' emerges from uncanny, uninhabitable places - with explicit reference to the work of Abdoumaliq Simone. Assuming the importance of dwelling and its immanence, can the political dimension ascribed by Lancione to the radical housing approach, be complemented with the affirmative politics of Esposito and Braidotti and Agamben's forms-of-life? Starting from these questions, this paper aims to engage with Lancione's dwelling as difference and offer a complementary readings suggesting the rubric of 'inhabitation' as the result of affirmative daily strategies of learning, navigating and governing the city. By expanding the notion of dwelling to include intersecting forms of caring, repairing and imagining the future, we will substantiate the concept we refer to as 'inhabiting' as a relational practice occurring in marginal and fragile environments, constituted by multiple incremental and transformative acts with the ultimate purpose to hold and resist marginalization.
\end{abstract}

Keywords: dwelling, inhabitation, ontology, affirmative politics, housing futures

\section{Introduction. 'Dwelling as difference'}

Lancione (2019) called "to look for 'radical housing' within everyday practices of dwelling at the margins, where the latter are understood as a site of resistance rather than a place of abnegation" (p.3) and a new way of "understanding the nuanced politics of housing and urban precarity" (p.2). Lancione invites readers to reframe the debate and the action from "a feminist and decolonial epistemology" (ibid), which entails an epistemological displacement of the housing question in order to focus on precarity as the site where "a politics of life" (ibid) emerges from uncanny and uninhabitable places (p.3) where a "form of 'dwelling as difference' that is able to challenge our compromised 'habitus' of home at its root" surfaces "from the ground of its everyday propositional unfolding" (p.3). 
Lancione sees housing as a radical gesture to questions not only an affordable access to a 'home' or a 'building' but also a mode of recognition that affirms a "different way of being in the city and in the world" (p.3). Social movements and radical experiences of housing collectives "use housing as a gateway to challenge wider structural forms of violence, including patriarchy, racism, class exploitation, and, of course, deprivation of shelter" (p. 3). Specifically, situating his reflections in the fertile territory across the British anarchism (Ward, 1976; Turner, 1976) and the collective agency of global south experiences (Bahn, 2019; Mitlin and Bartlett, 2018;) he suggests that "housing precarity and struggles are both a product and a producer of the urban political" (p.4). This suggests that radical forms of appropriation and direct actions configure alternative modes of urban production "away from top-down policy concerns towards a bottom-up politics of action" (p. 4). Advocating for a reconfiguration of the notion of dwelling across slums' collectives, squatters' movements and other progressive housing movements, Lancione proposes to "complement our current 'housing' language with a focus on the (un)makings of dwelling” (p.5).

Lancione's account of dwelling is framed with Deleuzian and Guattari's sensibility that resists an external recognition and definition and allows for a vital immanence of both "organized movements and individuals under precarious housing conditions" to develop "difference", which he defines as "the modality that cracks through the status quo, as the lived and embodied contestation of the habitual ground where life unfolds" (p.7) in minor, small and mundane actions. In his words again "the importance of (re)thinking the housing question through a 'recentering of dwelling"' (p.7) lies in the fact that, through the latter, we are invited to get closer to the place of action. While deliberately inspired by an ethnographical situatedness focusing on acts, performances and affects in the margins - that Simone calls 'rhythms of endurance' (2017) - is "not about romanticizing their traumatic becoming, but about challenging the silencing of their uncanny politics" (p.11). While surely 'dwelling as difference' engages with the notion of being in an ontological manner, the "epistemological displacement" (Lancione, 2019:2) through "feminism and decolonial" (ibid) tools suggested seem to pertain to an epistemological framework, even if expanded with the Deleuzian diversity and immanence. 
As with any emerging ideas in the engaged academic community, we had read Lancione's compelling work with interest and we wish to engage in what we hope will be a fertile conversation with some complementary although not necessarily different conceptual results. We will start by sharing our work and engagement with the biopolitical and thanatopolitical housing and sheltering praxis of refugees and migrants at the margins of the urban in Middle East, South East Asia and Southern Europe (Boano and Astolfo, 2020; Astolfo and Boano, 2019). Then, rather than embracing a Deleuzian ontology and the reification of the assemblages, we will attempt to go beyond the Heideggerian dwelling by grounding our reflection in the tradition of the affirmative politics of Agamben, Esposito and Braidotti to finally engage with the notion of forms-of-life as constitutive of our idea of inhabitation.

We seek to offer the rubric of 'inhabitation' as a contribution to the much needed recentering of dwelling to include intersecting forms of caring, repairing and imagining the future, as a relational practice. What we see as fertile is not the contrasting of 'dwelling as difference' with another conceptual register, but the charting of our engagement with multiple forms of life that, not only dwell in difference, but also develop forms of caring, repairing and imagining, to support, share and articulate further Lancione's political call for a renewed grammar of 'radical housing'. While in appearance 'dwelling as difference' and 'inhabitation' might differ as semantic constructions, they share the vitalist approach and an important ontological challenge of thinking being and being together as struggle of becoming. Inhabitation is not in opposition or an alternative concept of 'dwelling as difference' rather, seem to contribute to the same scholarly thinking.

The paper is structured in three parts. The first one examines the meaning and use of notions of inhabitance and un/inhabitability in contemporary literature and the similarities and differences with Lancione's 'dwelling as difference'; the second part delves into Esposito's and Braidotti's affirmative politics to elaborate on the notions of life and Agamben's forms-of-life as alternative or complementary to 'dwelling' and 'being' and to emancipate from immanence and biopolitics; the final part articulates and discusses a grammar of inhabitation through practices of caring, repairing and imagining as emerging from recent scholarship and our own work. 


\section{Positioning 'inhabitation' as relational ontology}

Often seen as synonymous of the verb dwelling, inhabitation is being used more and more in the literature. To illustrate the base of our argument trace the use of inhabitance, habiter and un/inhabitability in different work from Lefebvre's spatial politics and social theory, to Simone's ethnographico-theoretical urban sociology, to Escobar's feminist political ecology, as well as Agamben's philological-philosophical research.

\section{Lefebvre-inspired politics of inhabitance}

In the introduction of a special issue on Housing and the Right to the City, Rolnik (2014) writes that "to fully inhabit the city is to be able to unrestrictedly move around, what stresses the importance of accessible and comfortable public transportation, and also to be able to live in a well-located house" (p.293). Rolnik argues that housing retains a central role in urban struggles, and the 'condition of inhabitance' is central to the right to the city, clearly referring to Henri Lefebvre. Inhabitance, or habiter, for the French sociologist (2003), is the attribute that "should confer the right to participate in place-making, or in his terms the construction of lived space" (Darcy and Rogers, 2014:239). This signals a shift of power and control around the production of space from the state to the inhabitants (Purcell 2002).

More recently, a special issue of Citizenship Studies (Dadusc et all., 2019) examines systems of provision of housing by migrant and refugees in Europe, and how forms of appropriation and squatting create new forms of political subjectivity, urban commoning and inhabitance. The authors remind us that Lefebvre (2003) makes a distinction between habitat (habitat) and inhabiting (habiter) the latter being directly translated from the German wohnen, revealing Heidegger's influence. While habitat is defined as a container of living functions (eating, sleeping, working), habiter is conceived as the everyday practice of social space production that occurs outside coercive planning systems. They continue, "habiter, or inhabitance, is that which will always overflow, and it is often translated as living" (Dadusc et al, 2019:4). In the distinction between habitat and inhabitance, Dadusc et al. see the difference between housing and home, or state provision and self-provision. Inhabitance is proposed as a transgressive and subversive practice "that exceeds the politics of rights and 
citizenship" (p.9). Despite often associated with formal rights and citizenship discourses, "the right to the city is not a right to habitat, but a broader practice, that embraces forms of inhabiting" (p.4). In a similar vein, Purcell (2012) describes Lefebvre's habitat as an accumulation of alienated spaces that prevents dwellers from pursuing the act of inhabiter, "which is when inhabitants come to understand the conditions of their existence and resolve to collectively manage those conditions for themselves". While habitat serves the purpose of the capitalist reproduction, inhabiter offers a way out. All these variations are grounded in the Lefebrve-inspired scholarship or, in other words, in what Butler calls "politics of inhabitance" (2019:18; 2012). The term is used to describe the set of spatial relations where politics has at its centre the body, the occupation of space to contrast domination (aesthetical and in term of representation) as well as the anticipatory view of the future (utopia). It also serves as a fundamental reference call for a shift from the functionalist concept of the modernity of habitat (Butler, 2012:105) to the one of lived space (Soja 1996, 2010; Butler, 2012) so well established in the literature (Aalbers and Gibb, 2014; Darcy and Rogers, 2014; Weinstein and Ren, 2009).

\section{Habitus and un/inhabitability}

Another debate on inhabitance, lived space and marginality, focuses on the idea of un/inhabitability and the clash between normative politics, biology and environmental justice, centred on the socio-cultural connection between inhabiting, habitus and way of living. In cultural politics and practice, terms such as inhabitation, habitat, habit and habitus are strongly related given their origin from the Latin habeo, to have. For instance, the house refers to the place where we have the habit to sojourn, repeatedly and for long time. However, habitus, as related to inhabitation, might also refer to a normative way of living. In scientific terms, the inhabitability of an area depends upon its ability to sustain life (Rhodes, 2012 quoted in Woods, 2019). For example, the current scientific discourse on climate change suggests that if we continue to inhabit in a certain way, vast regions of the earth will no longer be habitable (Storlazzi et al. 2018; Collectif Argos, 2010; Wallace-Wells, 2017) referring to both Global South and North ways of living.

Uninhabitability is not only about spaces that cannot be inhabited, but also about ways of living that cannot be performed, and such distinction creates hierarchies of 
dominant and subordinate ways of living (Woods, 2019). "In other words, uninhabitable in these examples signifies, instead of biologically unliveable, a failure to meet a certain culturally defined conception of acceptability" (p.205). As cited in Woods, Simone (2016) moves his critique to the notion of uninhabitability by saying that it normalises a particular mode of inhabitation and creates a class of sub-humans (those who live inhabitable spaces). "Because these cities are widely considered to be the 'responsibility' of those who inhabit them, the fact that they appear as uninhabitable also renders their inhabitants not really or fully human" (Simone 2016a: 9). According to Woods, this ultimately normalises and establishes "a single, Eurocentric middle-class mode of habitation as the only viable mode of urban life" (p.203).

Simone shows great interest in people's ways to negotiate the apparent uninhabitability of places, questioning who decides what is uninhabitable and based on what criteria. Invisible or different as they might be, people always find ways to survive in the uninhabitable. Yet, "by categorizing these places as uninhabitable, one erases the attempts by people to make a life in those places" (Woods, 2019: 205). With Lefebvre, we could argue this is the triumph of habitat over habiter. What is relevant for the discussion here, is Woods' intuition around the conflation between biological life (liveability of a space) and cultural life (habitability of a place), and how both are measured on a western male-centred standard of wellbeing. Woods' argument is radically distant - if not opposite - from Agamben's politics of life (or dialectic of zoe/bios) as discussed later in the paper. However, it is useful to ground inhabitation into a politics of difference - that resonates with Lancione's dwelling as difference reducing the universalism that permeates and constitutes the limitation of Agamben's theory of life. Yet the question remains - how do we pursue environmental justice and recognise the cultural politics of inhabitation?

Woods argues that the logic of uninhabitability rather than being constructed on the universalisation of a single mode of inhabitation (as Simone would argue), is rather built on a negation, "a singular rootless subhuman other that never inhabits a space" (p.207). Ultimately uninhabitability becomes an othering process - and this, according to Woods, emerged with Heidegger's writing on dwelling which, rather than universalizing a mode of inhabitation, "condemns "a particular form of rootlessness, 
one that reflects the anti-Semitism to which Heidegger was drawn during his lifetime" (p.208). This is an issue upon that we will return later in the paper more explicitly.

\section{Decolonial inhabitability}

From a different perspective, Escobar (2019) in Geopolitics embeds the notion of un/inhabitability within a decolonial political ecological framework, getting closer to Lancione's call, but supporting more explicitly an ontological shift. In his writings, not dissimilar from the discourses that originated from Heidegger through Lefebvre, inhabitability is intended as being in the world and as being in relation. Inhabiting is a condition whose fundamental aspect is relationality. Yet, interactions do happen not only between humans, but also between humans and non-humans. Here lies the novelty. The essence of inhabiting and the single fundamental condition for the habitability of the earth consists of "the radical interdependence of everything that exists, the indubitable fact that everything exists because everything else does, that nothing pre-exists the relations that constitute it" (p.132).

For the sake of our argument in complementing Lancione's reflections, Escobar's contribution is important for two reasons. First, because it is embedded in his decolonial scholarship (Mignolo and Escobar, 2010) framed through the imperative to reconnect cities with the Earth to make them inhabitable again. Secondly, because he engages directly with an ontological approach which keeps the question of patriarchy, the role of nonhumans and the multiplicity of worlds firmly in view, and in so doing significantly contributing to the reconfiguration of urban studies (Cupples, 2019:217). In Design for the Pluriverse (2018), the Colombian sociologist extends his critique to modern civilisation which he sees as hegemonic regime of truth built on binaries (human/non-human, culture/nature, subject/object, reason/emotion). The current crisis of habitability is precisely generated by the separation of culture and nature, nature and society, urban and rural, and ultimately ascribed to the rise of cities in lieu of the dominant "hetero-patriarchal capitalist colonial" model of civilisation (p.133). Patriarchy in particular is the main reason for the erosion of relationality (p. 137). The only way to counter such crisis is to act upon inhabitation itself, meaning our way of being in the world. Escobar calls for a new notion of the human, a new way of life that is relational, that relates to all forms of life and plural sociocultural configurations. 
Thinking on inhabitation, it is necessary to recall the Heideggerian line of argument. For him, dwelling means being-in-the-world as a "human existence is an activity and is situated" (Waggoner, 2018:48) ${ }^{\mathrm{i}}$ and therefore inseparable to the notion of identity. However, the argument is problematic for at least two reasons. First, because it implies that dwelling is typically human; secondly, because it entails that those who do not dwell, or those who do not dwell in a certain way, are subhuman. With regards to the first point, both 'dwelling as difference' and 'inhabitation' offer the possibility to go beyond dwelling as proper to the human, especially if embracing a post-human turn (Diprose, 2011; Tonner, 2018; Braidotti, 2010; 2013). With regards to the second point, scholarship is still debating to what extent Heidegger's body of theory was conducive to nationalism and antisemitism (Rae, 2014; Trawny, 2019; O'Brien, 2020).ii With a very different take, and avoiding the point of antisemitism, Dungey (2007) sees an ethical responsibility toward togetherness behind Heidegger's idea of the being. Dwelling means understanding the self and, by difference, the other, with whom we are in relation. ${ }^{\text {iii }}$

There have been several interpretations of Heidegger's well known and overresearched argument. Conventional readers of Agamben might be surprised to learn he had recently offered a further philological exegesis (2019) of the concept of dwelling that could productively help in the argument here. Starting from Benveniste's (1973) interpretation of Indo-European etymological roots of the Latin words domus (home/heim) and aedes (house/haus), Agamben explains that the first term refers to the place where we dwell, while the latter refers to the physical building. The distinction between the terms domus/home and aedes/house is paradigmatic of the complexity of the social and material construction of dwelling, as well as its subjective and objective nature. This distinction is also problematic. If domus and aedes do not coincide in space, it means we dwell in places other than the house. Indeed, we dwell in places that are not homely at all. The meaning of dwelling exceeds the notion of house and home, and comes to mean 'being', 'being in a certain condition', 'belong' (to a group, a status, a nation) and also 'being in relation'. Ultimately, dwelling signals being in the world as condition of pure relationality. 
In the second half of the seminar, Agamben (2019) continues his philological exegesis by examining the Latin word, habitare which is linked to the verb 'to have'. With Benveniste (1973), Agamben argues that 'to have' is the reverse of 'to be' ('this is mine' is the reverse of 'I have it'). It results that 'to have' entails a condition of being, of being in a certain place, hence inhabiting. However, having and being differ in the sense that being entails an identity between 'who is' and the act of being; while having does not entail such identity, given that 'who has' and the object of possession are not the same thing. Going back to the meaning of inhabitation as to have and to be, Agamben argues that to have come to mean 'to have a certain way of being'. Accordingly, inhabitation is a way of being, a relational ontological category. Until this point, Agamben confirms and philologically validates Heidegger's relational ontology of dwelling. The following argument, however, is contra Heidegger. While Heidegger argues that building (bauen/edificare) means dwelling (buan/habitare) because we build to dwell, Agamben argues that building and dwelling have ceased to be an identity, and this leads to our current inability of building habitable spaces.

The separation of building and dwelling occurred with the birth of professionalism, when building was institutionalised as discipline, and the architect as builder became detached from the inhabitant as dweller. Such reading is problematic, as it ignores the vast auto-constructed urban environments in the world. Yet the idea of a rupture of the original identity of dwelling and building is indeed important to understand the current condition of uninhabitability. Agamben exemplifies such condition through the paradigm of the camp (Boano, 2019): a place that can be built, but where we cannot dwell. Building uninhabitable places is the negation of the historical a priori of architecture: to inhabit. Agamben reaches the same conclusion as Woods and Simone, yet through a very different path.

\section{Approaching inhabitation as Affirmative Biopolitics with Esposito and Braidotti}

In Lancione's paper, dwelling as difference happens at the 'margins'. Our engagement with the 'margins' was originally influenced by biopolitics and thanatopolitics (Murray, 2006;) as a manifestation of Foucault's political technology (Foucault 1990:252). In his formulation, biopolitics tended to invoke a division between worthy and less worthy life, one that is rooted, many argue, in a Heideggerian foundational 
distinction between proper and improper life (Agamben, 2002; Campbell, 2011). After we had witnessed the manifold inoperative gestures put in place to resist and reimagine life beyond the control of violence, Agamben's thoughts emerged in all their political complexity (Boano 2017; Bonacci 2019). In particular the concept of form-oflife (forma-di-vita), intended as eminently political life, a life beyond the control of any biopolitical machines, that allows emancipation and enables a project of affirmation. Through acts of disengagement, deactivation, subtraction, inversion and suspension, Agamben's notion of life is experienced as a threshold "between speech and noise, political life and nude life, human and animal and a new ethics is to be found" (Boano 2017:163) occupying "the zone of indistinction where life is neither silent and passive, not fully captured in language and actions" (Colebrook and Maxwell 2016: 95).

However, the critique to Agamben's anthropocentrism (Lemke, 2005; Braidotti, 2015; Vatter, 2017), the disciplinary dilemmas and the expansion of biopolitical turns (Lemke, 2015; Pozorov, Rentea, 2017) led us to venture in the Italian Thought of Roberto Esposito and the neo-materialist post-humanism of Rosi Braidotti. Their work converges in what they have called, affirmative biopolitics. Both authors, even if differently, are somehow engaging - more or less explicitly in the case of Esposito with Deleuze, and - in the case of Braidotti - with situated knowledges and feminist theory.

Esposito understands affirmative biopolitics within the realm of political theory, aesthetics and political theology. Reflecting on Nazi biopolitics, he argues that "whereas biopower under Nazism thinks the relation between life and politics only 'biologically,' the aim of an affirmative biopolitics is 'to interpret life's relationship with politics philosophically" (Esposito, 2008: 150). Esposito's notions of affirmation is articulated as a tension between the body and the flesh, in contrast with Agamben. According to Vatter, "it is not so much a question of formulating a form-of-life that is entirely outside of law. Rather, the goal is to think about rights by shifting the emphasis from person to impersonal, from body to flesh, such that rights can make possible a co-immunity between individuals rather than the preservation of their reified individual interests" (Vatter, 2017:136) calling for a life "that it can acquire "the power [potenza] of life's becoming' and live up to the principle that 'no part of life can 
be destroyed in favor of another: every life is a form of life and every form refers to life' (Esposito 2008:194).

Roberto Esposito's version of affirmative biopolitics proceeds from a radical reversal of the conventional biopolitical logic. Esposito's paradigm of 'immunization' accounts for the logic and functioning of dispositifs of biopower that work by flattening "the political into the purely biological" and that politicizes the biological as much as they biologize the political (2008: 146-7). His Communitas (1998) and Immunitas (2002) develop the thesis that the modern subject, with all of its civil and political rights, emerges as an attempt to attain immunity from the contagion of what is extraindividual; namely, the possibility of radical community. Esposito's affirmative biopolitics turns on the "deconstruction" of the dispositifs that identify a kind of life not worthy of being lived and employs the concept of 'flesh' to argue for the irreducibility of bios-logical life into biology. Quite important for our relational dimension of inhabitation, through this distinction between flesh and body, Esposito works out a concept of life that is inherently exposed to the world and to others, and thus cannot be the object of preservation or of immunization of the self, as happens when life is reduced to the body and its self-enclosure.

On the other side, Braidotti's theories on vitalist materialism energetically "displace anthropocentrism" (2016:44) and challenge the negative dimension of biopolitics. For her affirmative biopolitics "indicates the processes of transmuting negative passions into productive and sustainable praxis, which does not deny the reality of horrors, violence and destructions [...] but proposes a different way of dealing with them" (p.51). Such vitalist materialism, not different from Lancione's assemblages in the margins, is a praxis that endures positivity "by propelling social conditions and relations [...] undoing existing arrangements and to actualise productive alternatives" (p.52). This can help us to imagine a notion of alternatives to 'dwelling' and 'being' to emancipate from immanence and biopolitics.

Despite Braidotti's reflection stemming from a critique of Agamben's negativity, her forms of life are not something external but already present in the process of affirmation. In other words she sees an "emancipation as the actualisation of the virtual past, an idea that never quite made it but never quite died, either. Completely 
present, completely antiquated, completely part of a present that is trying to become actual - a sort of never-dead, always about to burst into life" (Braidotti 2019:468). For her, "the common denominator for the posthuman condition is an assumption about the vital, self-organizing and yet non-naturalist structure of living matter itself" (2013:2). The posthuman body is seen as being multiple and relational and framed by multiplicity, embodiment, sexuality, and affectivity (Braidotti 2013: 26,49). Braidotti reads the current present biopolitical conditions that fuel identity politics and the perennial warfare of our times introducing a political economy of negative passions in our social context. This negative affective economy constructs our lives in a militarized social space, under pressure of increased security enforcement and escalating states of emergency (Braidotti 2010). Affirmation in Braidotti's work is thus understood as "how to engage in [...] the creation of sustainable alternatives geared to the construction of social horizons of hope, while at the same time doing critical theory, which implies resistance to the present." For her, central to this "[...]is the question of how to resist the present, more specifically the injustice, violence, and vulgarity of the times, while being worthy of our times, so as to engage with them in a productive, albeit it oppositional and affirmative manner". Affirmation is "an ethic of joy", where resistance and future sits in a gesture that is "the actualization of our increased ability to act and interact in the world.

Having sketched the intellectual trajectories of affirmation and the centrality of life in their forms, in their commonality (impersonality) and vitalistic dimensions, lead us to reflect on inhabitation as more than dwelling. Esposito's and Braidotti's affirmative politics and Agamben's forms-of-life help us think of alternative or complementary meanings for 'dwelling' and 'being' and to emancipate from immanence and biopolitics. Particularly, we can envision three key characteristics of an affirmative life: the capacity to care and to connect, the capacity to repair, endure and hold together, as well as to imagine and experiment alternatives as antagonistic potentials of lifeforces to oppose politics of oppression and capitalist extraction of values. With and beyond Heidegger's dwelling, with a focus on life and living (collectively) suggested by Agamben - central to any serious discussion on housing and urbanism - and extended beyond anthropocentrism to embrace a more vitalist materialism - to avoid the relativist idea of the existence of a multiplicity of forms-of-life - inhabitation thus becomes the territory where practices of care, repair and imagination forge renewed 
politics and an ontology of the living. This fosters the space for territory that call ‘inhabitation’ to emerge.

Esposito's and Braidotti's affirmative politics to elaborate on the notions of life and Agamben's forms-of-life as alternative or complementary to ‘dwelling' and 'being' and to emancipate from immanence and biopolitics; the final part articulates and discusses a grammar of inhabitation through practices of caring, repairing and imagining as emerging from recent scholarship and our own work.

\section{Inhabitation as a form-of-life, or maybe-life as a form-of-inhabitation}

Working with the active grammar of forms-of-life, we arrived at inhabitation as a system, a network of forms of life through our work on camps and their spatialities; spaces intended as an eminently political life, a life beyond the control of any biopolitical apparatuses or anthropological machines.

This, the semantic horizon, the affirmative gesture of inhabitation - in the ethical relationship with space, as space of and for life - materialises in acts of repairing, caring and of course, imagining "new ethics, reversing its status as a productive and active force" (Boano, 2017:163). Life is experienced as a threshold and therefore, forms of life and their gesture are probably the point with more convergence with Lancione's Deleuzian immanence: a life and nothing more, or in Cimatti's words "not immanence to life, but the immanent that is in nothing, is itself a life" (2019:498). This is a life, without a "biological vocation, not determined by whatever necessities" (Salzani 2013:135), but a life "in which the single ways, acts and processes of living are never simply facts but always and above all possibilities of life, always and above all power" (Agamben 2000:3,4). The forms of life that presuppose inhabitation, become conceptual dispositives to retthink how we live together and phenomenological and practical dimensions, and also how the norms and the tactics of such life get configured. Here, Wittgenstein's concept of Lebensformen, which Agamben refer directly to, get into the picture. Hanna Pitkin offers a good summary of Wittgenstein forms of life: "Because they are patterns, regularities, configurations, Wittgenstein calls them forms; and because they are patterns in the fabric of human existence and activity on earth, he calls them forms of life" (1973:132). Such reading allows us to move from the realm of abstract language to societal material relations. ${ }^{\text {iv }}$ Spatialising 
forms of life is also important, and Rahel Jaeggi's work is instrumental in this regard. She refers to forms of life as "a culturally informed order of human co-existence that encompasses an ensemble of practices and orientations; as well as their institutional manifestations and materializations". She continues, "Differences between forms of life are not only expressed by different beliefs, values and attitudes, they are also manifested and materialized in fashion, architecture, legal systems and family organization" (Jaeggi 2015:16).

The plurality of the forms of life and the irreducibility of the conflicts that such plurality implies points to the conditions of possibility of caring, repairing and imagining where "its powers are simultaneously structural and relational, recursive and emergent" (Amin and Thrift 2017:48). A territorial perspective, a spatial outlook of such forms of life casts cities, neighbourhoods and communities, not only as sites of refuge, but as spaces where rights can be produced; spaces where the 'struggle' for inhabitation takes place.

\section{Approaching inhabitation}

Spatializing inhabitation means therefore speaking with a renewed grammar of radical housing and city-making that converge with Lancione's situated practices and ethnographic work on the margins as an ontological exploration. Our engagement with refugees and migrants, and with the ontological erasure of urban realities in perpetual state of conflict, allows us to think, in a complementary way, to such immanence with an ontology that stresses the 'political stakes of the question of being' as "think[ing] the political through the exigency of the ontological question" (Abbott, 2012:24). Shifting the language from housing to dwelling and from dwelling to inhabitation, we see the important shift to an ontology of the urban as "ontology of a certain form of human being-with-others" (Azoulay, 2012:52). This vision of ontology is therefore to be seen away from the conventional existence of a perfect and always real truth. Ontology hence does not invoke essence, even if radical, but rather an "arrangement of existents" (Povinelli, 2014) to which humans and non-humans are oriented and attempt to stabilize. In other words, thinking the project of inhabitation becomes in essence already an ontological operation. that is paraphrasing Povinelli, according to whom the endurance of alternative forms of lives opens new "otherwise" (ibid:32). Understanding the affirmative dimension of inhabitation as a resistance to the 
biopolitics of housing allows us to develop enduring, affirmative relations of subjects that tenaciously respond non-negatively to aspects of life and to modes of living and extractive practices and construct different horizons of hope.

Therefore, attempting to summarise, the choice to suggest the register of inhabitation is to be located at the crux of different gestures. The first, we share with Lancione, is to strip dwelling from the sole Heideggerian frame, although we agree it is a fundamental reference. While Lancione moves beyond Heidegger by embracing difference, we use Giorgio Agamben's engagement with Heidegger and the critique to the anthropocentric dimensions of the animality, of the negation and the notion of use. Contemporary continental philosophy is indelibly marked by Heidegger's influence and implications for phenomenology, deconstruction, aesthetics, the history of philosophy, literature, the arts, theology and architecture relevance, generally and with dwelling specifically. The point is therefore for us not 'confronting' with dwelling but, paraphrasing Matteo Acciaresi, being in 'convergent disagreement'.

The second gesture was to strip, and this is somehow also shared with Lancione, the anthropocentrism and the sole humanism of the notion of dwelling to expand it toward an ethos for living grounded in posthumanism and material feminism, using works by thinkers as Rosi Braidotti among others, that de-center the human, re-position it in its ecosystem and, while remaining attentive to difference, foster the thriving of all instances of life. However, its origin can still be traced in the critical quest of metaphysical debates, somehow anticipated in the discipline of geography by Castree (2003) and following Hinchliffe's idea of inhabitation as "more than human affair" but not simply as matter non-human. ${ }^{v}$ Also, the abandonment of anthropocentrism for us was an alignment to the call for a feminist and decolonial approach to the housing debate. However, in such a reading, we get closer to the language of inhabitation, rather than dwelling. Specifically, Lugones (2010) in discussing and criticizing colonial modernity centrally constructed on the dichotomy of human and non-human, suggests that "resistant subjectivity often expresses itself infra-politically, rather than in a politics of the public, which has an easy inhabitation of public contestation" (p.746). Such forms of inhabitation, recalls Hartsock, positing that "those of us who have been constituted as sets of negative qualities need to engage in the historical, political, and theoretical process of constituting ourselves as subjects as 
well as objects of history, subjects who inhabit multiple, superimposed, and opposed realities" (p.32).

The third gesture that helped shape the rubric of inhabitation was embracing the "notions as "life" as it is elaborated through the Italian Thoughts (Esposito, 2012) focusing on the relationship between life and politics in the grammar of forms-of-life, emerged from a critical reconfiguration of supremacy of language, that is "flattened on the side of the epistemological rather than on the bio-political" (Garofalo, 2015: 140). This is not exclusive to the vivid application of Foucauldian biopolitics so central in Agamben's work, but more as an explicit philosophy of life, in its continuous tension between politics and history, where living and being in the world is an "industrious activity not finalized to the subsistence and obedience but to the creation and the individual or collective autonomy" (Ciccarelli, 2015: 151). Researching the "burning house" (Boano, 2017:17) of the biopolitical regime of the current urban environment and housing "allowed for a fruitful reflection on alternative modes, or emancipations, that aim beyond simple biopolitics into a project of affirmative biopolitics and explorations of multiple forms-of-life.

\section{A provisional definition of Inhabitation and its political forms-of-life}

The rubric of 'inhabitation' is a contribution to the much needed re-centering of dwelling to include intersecting forms of caring, repairing and imagining the future, as a relational practice occurring in marginal and fragile environments and constituted by multiple incremental and transformative acts with the ultimate purpose to hold and resist marginalization. Three constitutive elements of inhabitation can be briefly elaborated below. vi

\section{Forms-of-caring}

The notion and the practice of care is for us quite important in the enquiry on the forms-of-life. Maria Puig de la Bellacasa (2017) posits that care, as a practice of the everyday and the uneventful, can in fact be a radically transformative political project as it is materialized in the forms of life-sustaining webs. She lays out her understanding in a triptych form, joining together an affective state, a form of practice (what she calls a "material vital doing"), and an ethico-political obligation. Power and Mee (2019) go even further conceiving housing as "care infrastructure [...] as a 
sociomaterial assemblage that is constitutive of care" framing a substantial connection between "care, housing and home through centring care within an analysis of the house-as-home" (p.2). Inhabitation is then made by the concrete work of care, which is implicated in shaping, forming and negotiating vital politics to a disposition to "care about," without putting in the work to "care for" (Tronto, 1993). Being both a set of discourses and practices, what for us is important is its nature of "affective connective tissue [...] between people, environments, and objects [where] reciprocity and attentiveness to the inequitable dynamics that characterize our current social landscape allow us to envision what Elizabeth Povinelli describes as an otherwise" (Hobart, Kneese, 2020:2). When caring practices, individual and collective are at play in inhabitation they make the term broader than dwelling per se, although it incorporates it as well, as the notion of habitus and habitual (which are part of its linguistic genesis) and make them "political questions about the ways that care is imagined and patterned through housing" (Power, Mee, 2019:3). Care leads us to think housing as an extended territory. In turn, we see inhabiting as a relational form of care that concerns us as a collective, and our imagination, therefore as a political body. Care, as a process of holding together (materialities and temporalities), is conducive to notions of maintenance, repair and imagination.

\section{Forms-of-repairing}

If pessimism and negativity were the conventional critical dimensions of any approach to inhabitance and given the degree of brokenness of a broken world, repair and maintenance have now become crucial components for redefining sociopolitical imaginaries (Jackson, 2014; Strebel, et all. 2019). The "repairing regimes of practices" (Graziano and Trogal, 2019:204) are indeed crucial to support the relational approach to inhabitation as more-than-dwelling. Inspired certainly by the extensive tradition of feminist thought (Jackson, 2014), the "constellation of repair concepts, figures and gestures" (Graziano and Trogal, 2019:204) sustains the way in which in realities, material and symbolic, characterize the urban environment and everyday life. Repair is clearly foundational to autoconstructed materialities that characterize the urban environment and everyday life and question the way in which individuals and the collective build "physical infrastructures that support ecologies of care" (2018, n.p.) involving always elements of adaptation and improvisation (Graham and Thrift, 
2007). Bahn (2019) suggests that repair - when conceived as an assemblage of practices - is able to restore immediate function over the need for substantive material improvement. More specifically, repair is immanent and does not always presuppose institutional actors. Everyone can, should, and generally does, repair in some form there are no particular professionals whose "sector" or "domain" is repair. Repair can hence be seen as a mode of practice that draws upon forms of both public and proximate knowledge. When dwelling is extended with repair, in addition to become another infrastructure of care, allows the emergence of an ontology that is intrinsically pragmatic and performative" (Mercier, 2019:6). Mattern suggests that "we are never far from three enduring truths: (1) Maintainers require care; (2) caregiving requires maintenance; and (3) the distinctions between these practices are shaped by race, gender, class, and other political, economic, and cultural forces" (2018). In other words the relational dimension infused in such practices could be interpreted as political ontologies to relate to the political stake of the question of being and becoming affirmative, allowing the possibility of different ways of living and forms-oflife have the potential to transform or resist modes of dominance over life, generated by the rupture and the obsolescence of the world. While being a distinctively 'spatial' and 'southern' practice, the double significance of the verb repair, intended both as to restore something broken and to protect, connects its clearly to use, space, commons and materiality and simultaneously becomes an imaginative practice, playing a fundamental role in connecting past (ruination) and future.

\section{Forms-of-imagining}

Inhabitability should not be defined "a-priori, but traced as it emerges from uncanny places, uninhabitable 'homes' and multiple violent histories” (Lancione, 2019:3). Such focus on life, its emergence and its forms suggest not only a radical possibility (ibi) and a vital immanence (Braidotti) but "an ontology of the act, of the agency of actors, whatever their ontological status (human, non-human, objects, gods and earth beings, etc.)" (Mercier, 2019:6). Alongside the material practices of inhabitation in the dwelling-expanded-form, an affirmative dimension does not simply focus on the endurance and the present but the difficult task of imagining a possible future that supports the emergence of new affirmative forms-of-life re-composed in response to an "uncontainable materiality" (ibid) in an "ontological multiplicity" (ibid:176) across 
past, present and future. The supremacy of the epistemological in discussing and researching housing and urban issues are not sufficient to define inhabitation that need to be complemented with what both Lancione and Escobar suggested: a decolonial approach is to situate action in and along struggles and to embrace of a pluriversal vision of the future as "a strategic response to the excess and violence of universalism and Western imperialism" (Mercier, 2019:2). What specifically interests any reflection on inhabitation is not only in the fundamental operation of an epistemic 'enlargement' and delinking with the adoption of a much wider and situated literature but "a pluralistic ontology or an ontological pluralism" (Mercier, 2019) where "new modes of dwelling can be imagined and designed by incorporating relational modes of living into urban landscapes" (Escobar, 2019:138). Inhabitation is thinking and imagining the future, beside "bodies, ideas, identities of all kinds are the provisional alignment of a physics of forces, which gives "blood," that is power, energy, to all things" (Grotz, 2017:311). A more dynamic process of formation and imagination becomes a space in which many meanings, bodies and materials operate in public, in motion. Inhabitation as imagination is therefore where both "ethics and politics" that are respectively "our manner of living in the world with others" and "our mode of collective contestation of the ways in which such forms of living occur, and their costs, in the world" allow us to think on "not only what is, but how what exists or is might enable what doesn't (yet) exist but could exist” (Grosz and Hill, 2017:8).

\section{Towards a renewed grammar of inhabitation}

The "crisis of habitability" (Escobar, 2019:132) and the recentering of dwelling (Lancione, 2019) as central dimensions of radical housing research have motivated us to contribute to the debate with an immanent and affirmative thought we called 'inhabitation' as more-than-dwelling. The adoption of it is not a simple metaphorical exercise, nor semantic determinism in the traditional global themes of housing research; instead, it means a comprehensive style of thought that is "oriented by spatial relations, the way in which we imagine what to think" (Colebrook 2005a: 190). As we wish to expand and transcend dwelling with an affirmative politics vision and the of form-of-life, the only condition upon which resistance to biopolitical apparatuses becomes possible. Esposito argues that "every political thought implies a conception of space, of time, of the world, of human. On the other hand, every 
philosophical definition of being necessarily has political effects. On the other hand, any mode of being - starting from its very 'being able' to be - is what expresses the political tension of the relationships from which it is generated and which it tends to modify "(Esposito, 2019:23). The practices of inhabitation exceed dwelling with care, repair and imagination and allow for the expanded immanence of housing practice that have emerged in the struggles of recognition and materiality. Paraphrasing Agamben, processes of living are never simply facts but always and above all possibilities of life.

\section{References}

Aalbers, M, Gibb, K. (2014) Housing and the Right to the city: introduction to the special issue. International Journal of Housing policy, 14(3), 207-13.

Abbott, M. (2014) The figure of this world. Edinburg University Press.

Agamben, G. (2019) Abitare e Costruire. 9 July 2019. Available at https://www.quodlibet.it/giorgio- agamben-abitare-e-costruire. Accessed 10 August 2019.

Amin A., Thrift, N., (2017) Seeing like a City. Cambridge: Polity Press.

Astolfo, G, Boano, C. (2019) Affordable housing policy and practices: case study review. London. DPU.

Azoulay, A. (2012) Civil imagination: a political ontology of photography. Verso. London.

Bahn, G. (2019) Notes on a Southern urban practice. Environment and Urbanization. https://journals.sagepub.com/doi/10.1177/0956247818815792

Barnesmoore, L. (2018) Editorial: The right to assert the order of things in the city. City. 22 (2), pp:183-200.

Bayat, A. (2000) From 'dangerous classes' to 'quiet rebels': politics of the urban subaltern in the global South. International Sociology, Vol. 15 (3), pp: 533-557.

Benveniste, E. (1973) Indo-European Language and Society. Coral Gables: University of Miami Press.

Boano, C. (2019) From Exclusion to Inhabitation: Response to Gray, Benjamin. Citizenship as Barrier and Opportunity for Ancient Greek and Modern Refugees. Humanities, 8, 125, 1-8.

Boano, C. (2017) The ethics of a potentialurbanism. Critical encounters between Giorgio Agamben and architecture. Routledge, London.

Boano, C., Astolfo, G. (2020) Notes around Hospitality as Inhabitation. Engaging with the Politics of Care and Refugees' Dwelling Practices in the Italian Urban Context. Migration and society. (forthcoming April 2020).

Bonacci, V. (2019) Giorgio Agamben. Ontologia Politica. Macerata: Quodlibet. 
Braidotti, R. (2013) Posthuman humanities. European Educational Research Journal. 12(1):1-19.

Braidotti, R. (2010) The politics of 'life itself' and new ways of dying. In D. Coole, et a (eds) New materialisms: ontology, agency and politics. Duke university press. 201-220.

Braidotti, R. (2015) The posthuman in feminist theory. In: Disch, Lisa and Hawkesworth, Mary (eds) Oxford Handbook of Feminist Theory. Oxford: Oxford University Press.

Braidotti, R. (2019) Affirmative Ethics and Generative Life, Deleuze and Guattari Studies, Vol. 13(4), pp: 463-481.

Butler, C. (2012) Henri Lefebvre. Spatial politics, everyday life and the right to the city. Routledge

Butler, C. (2019) Public housing on the rocks: brutalism, heritage and the defence of inhabitance. Acta Academica, Vol. 51(1):4-27.

Castree, N. (2003) Environmental issues: relational ontologies and hybrid politics. Progress in Human Geography. 27(2):203-11.

Ciccarelli, R. (2015) Abitare l'immanenza. Logica, Storia e Politica di un Concetto nel Pensiero Italiano, in D. Gentile and E. Stimilli, eds, Differenze Italiane. Politica e Filosophia: Mappe e Sconfinamenti. Rome: Derive Approdi, pp. 150-169.

Cimatti, F. (2019) Deleuze and Italian Though. Deleuze and Guttuari Studies. Vol.13(4), pp:495-507.

Colebrook, C. (2005) Deleuze and the meaning of life. Deleuze and philosophy. Edinburgh University Press. pp: 121-132.

Collectif Argos. (2007) 2010. Climate Refugees. Cambridge, MA: MIT Press.

Cupples, J. (2019) Thinking ontologically and making do with development A response to Escobar. Geoforum, Vol. 101:215-217.

Darcy, M., \& Rogers, D. (2014). Inhabitance, place-making and the right to the city : public housing redevelopment in Sydney. International Journal of Housing Policy, 14(3), 236-256.

Dadusc, D, Grazioli, M, Martínez, M. (2019) Introduction: citizenship as inhabitance? Migrant housing squats versus institutional accommodation, Citizenship Studies.

De la Bellacasa, M. (2017) Matters of care. University of Minnesota press.

Di Cesare, D. (2014) Heidegger e gli ebrei. I “Quaderni neri”. Bollati Boringhieri, Torino

Diprose, R. (2011) Building and Belonging Amid the plight of Dwelling. Angelaki, Vol 16(4), pp:59-72.

Dungey, N. (2007) The ethics and politics of dwelling. Polity, 39(2):234-58.

Escobar, A. (2018) Design for the Pluriverse: Radical interdependence, autonomy, and the making of worlds. Durham and London: Duke University Press.

Escobar, A. (2019) Habitability and design: radical interdependencies and the reearthing of cities. Geoforum, 101:132-140.

Esposito, R. (2008) Bios: biopolitics and philosophy. Univrsity of Minnesota Press. 
Esposito, R. (2010 Communitas. Origin and destiny of the community. Stanford University press.

Esposito, R. (2011) Immunitas: the protection and negation of life. Trans Zakiya Hanafi. Cambridge: Polity.

Esposito, R. (2012[2010]) Living Thought: The Origins and Actuality of Italian Philosophy. Stanford University Press.

Foucault, M. (1990) The History of Sexuality. An Introduction, Volume 1. New York: Vintage Books.

Garofalo, P. (2015) Linguaggio e Bio-politica nel Dibattito Italiano Contemporaneo. Rivista Italiana di Filosofia del Linguaggio, Vol. 9(1), pp. 122-145.

Gier, F.N. (1980) Wittengstein and Forms of Life, Philosophy of the Social Science, Vol.10, pp:242-258.

Graham, S. Thrift, N. (2007) Out of order: understanding repair and maintenance. Theory, culture and society, 24(3):1-25.

Graziano, V. Trogal, K. (2019) The politics of collective repair: examining objectrelations in a postwork society. Cultural studies, 31(15):634-658.

Hartsock, N. (1990) The Construction of Gender and Modes of Social Division. Cultural Critique, No. 14, (Winter, 1989-1990), pp. 15-33.

Hinchliffe, S. (2002) Chapter 10: 'Inhabiting' - Landscapes and Natures. In: Handbook of Cultural Geography. Edited by: Kay Anderson, Mona Domosh, Steve Pile and Nigel Thrift.

Hi'ilei Julia Kawehipuaakahaopulani Hobart, Tamara Kneese (2020) Radical Care Survival Strategies for Uncertain Times, Social Text, 38 (1 (142)): 1-16

Jackson, S. (2014) Rethinking repair. In Media Technologies: Essays on Communication, Materiality and Society, ed. Tarleton Gillespie, Pablo Boczkowski, and Kirsten Foot. Cambridge: MIT Press.

Jaeggi, R. (2015) Towards an Immanent Critique of Forms of Life. Raisons politiques 2015/1, N 57, pp: 13-29.

Lancione, M. (2019) Radical housing: on the politics of dwelling as difference, International Journal of Housing Policy.

Lefebvre, H. (2003) The Urban Revolution. Minneapolis: University of Minnesota Press

Lemke, T. (2005) “A Zone of Indistinction” - A Critique of Giorgio Agamben's Concept of Biopolitics. Outlines. Critical Practice Studies, 7(1), 3-13.

Lemke, T. (2015) New Materialisms: Foucault and the 'Government of Things'. In Theory, Culture \& Society.

Lugones, M. (2010) Toward a Decolonial Feminism. Hypatia, Vol.25(4)

Mattern, Shannon. "Maintenance and Care.” Places, November 2018. Placesjournal .org/article/maintenance- and- care/.

Millington, N. (2019) Critical Spatial Practices of Repair. Society and Space Mignolo, W, Escobar, A (2010) Globalization and the decolonial option. London, New York: Routledge.

Mitlin, D., Bartlett, S. (2018) Editorial: Co-production - key ideas. Environment and Urbanization, Vol. 30(2):355-366. 
Murray, S.J. (2006) Thanatopolitics: On the Use of Death for Mobilizing Political Life. Polygraph, Vol. 18, pp. 191-215.

O'Brien, M. (2020) Heidegger's Life and thoughts. A tarnished legacy. London: Rowman \& Littlefield.

Pitkin, H.F. (1973) Wittgenstein and Justice. On the Significance of Ludwig Wittgenstein for Social and Political Thought. University of California Press.

Purcell, M. (2002) Excavating Lefebvre: The right to the city and the urban politics of the inhabitant. GeoJournal, 58(2-3), 99-108.

Purcell, M. (2012) Lefebvre, Habitat and the dystopia of contemporary public university. Available at https://www.google.com/amp/s/pathtothepossible.wordpress.com/2012/o9/14 /lefebvre-habitat-and-the-dystopia-of-the-contemporary-publicuniversity/amp/ Accessed 29/12/2019

Power, E.M, Mee, K.J. (2019) Housing: an infrastructure of care. Housing Studies. Received 20 Jun 2018, Accepted 23 Apr 2019, Published online: 14 May 2019.

Pozorov, S., Rentea, S. (2017) The Routledge Handbook of Biopolitics. London: Routledge

Rae, G. (2014) Ontology in Heidegger and Deleuze, Palgrave Macmillan.

Rhodes, F. (2012) Earth: A Tenant's Manual. Ithaca, NY: Cornell University Press. Rolnik, R. (2014) Place, inhabitance and citizenship: the right to housing and the right to the city in the contemporary urban world. Journal International Journal of Housing Policy, 14(3)

Simone, A. (2017) Ensembles of the Uninhabitable. Smuts Memorial Lecture Series: The Uninhabitable: Afterlives of the Urban South. 7 November 2017.

Simone A. (2004) People as infrastructure. Intersecting Fragments in Johannesburg. Public Culture, 16(3):407-429.

Simone, A., (2016) The Uninhabitable? In between Collapsed Yet Still Rigid Distinctions, Cultural Politics, 12(2):135-154.

Simone, A, Pieterse, E. (2017) New Urban Worlds. Inhabiting Dissonant Times Polity Press, Cambridge, U.K

Soja, E.W. (2010) Seeking Spatial Justice. Minneapolis: University of Minnesota Press

Soja, E.W. (1996) The extraordinary voyages of Henri Lefebvre, pp. 26-52; The trialectics of spatiality. In: Thirdspace: Journeys to Los Angeles and other realand-imagined places. Blackwell, Oxford, 53-82.

Storlazzi, C., et al. (2018) Most Atolls Will Be Uninhabitable by the Mid-Twenty-First Century Because of Sea-Level Rise Exacerbating Wave-Driven Flooding. Science Advances 4, no. 4:1 - 9.

Strebel, I., Bovet, A., Sormani, P. (2019) Repair Work Ethnographies Revisiting Breakdown, Relocating Materiality. London: Palgrave.

Tonner, P. (2018) Dwelling: Heidegger, archaeology, mortality. Series: Routledge studies in archaeology. Routledge: London.

Trawny, P. (2019) Heidegger. A Critical Introduction. Cambridge: Polity Press. 
Tronto, J. (1993) Moral Boundaries. A Political Argument for an Ethic of Care. London Routledge.

Vatter, M.E. (2017). Community, life and subjectivity in Italian biopolitics. In Sergei Prozorov, and Simona Rentea, ed. The Routledge Handbook of Biopolitics. New York: Routledge., pp. 123-139.

Waggoner, M. (2018) How Not to Be at Home in One's Home: Adorno's Critique of Architectural Reason. Architecture Philosophy 4 (1) (2019).

Wallace-Wells, D. (2017) “The Uninhabitable Earth, Annotated Edition.” New York Magazine.

Ward, C. (1976) Housing: An anarchist approach. London: Freedom Press.

Weinstein, L. and Ren, X. (2009) The changing right to the city: urban renewal and housing rights in globalizing Shanghai and Mumbai. City and Community 8.4, 407- 432.

Wilhelm-Solomon, B. (2017) The ruinous vitalism of the urban form: ontological orientations in inner-city Johannesburg. Critical African Studies, 9(2):174-191.

Woods, M. (2019) Hospitality; or, a Critique of Un/inhabitability, Cultural Politics, 15(2): 202-222. Zartaloudis, T. 2015 Agamben and law. Routledge, London.

\section{Endnotes}

\footnotetext{
i O'Brien (2012) hits the core of this complex discussion saying that "Heidegger is, without question, one of the most important philosophers of the twentieth century [...] The idea then that one should simply strike Heidegger's name from the canon and ignore his work betrays a profound ignorance of the magnitude of Heidegger's intellectual achievements, not least since it presumes that many of the most important intellectual figures from the second half of the twentieth century right through to today, who acknowledge a major intellectual debt to Heidegger, were either too blind or too stupid to notice that Heidegger's philosophy is simply the abstruse mysticism of a charlatan or the work of a dangerous Nazi hack" (p.10)

ii Di Cesare (2014) argues that Heidegger's antisemitism is ontological rather than race-based: "that Jews would be relentlessly devoted to the task of uprooting all beings from being. The stereotype of the wandering Jew here reaches ontological proportions, spreading their homelessness to all they encounter in an ontological uprooting of beings from being" (Mitchell \& Trawny, 2017).

iii The human being is certainly at the centre; yet, in a non-domineering position, as the main human function is to care for the other. Caring for is the relational function of being and dwelling. I dwell hence I care. Dungey concludes that "modes of caring are ontologically constitutive of who we are" (2007:241) and this constitutes the ethical (and political) dimension of Heidegger's being.

iv Gier (1980) reconstructs the concept of Lebensformen around four interconnected levels: "(1) a biological level from which (2) unique human activities like pretending, grieving, etc. are then expressed in (3) various cultural styles that in turn have their formal ground in a (4) general socio-linguistic framework (Wittgenstein's Weltbild)" (p. 245).

v Questioning the non-representational theory he uses the register of inhabitation to not simply as a liberation but as "experimenting with styles of inhabiting, styles that manage to re-cover and re-cognize without covering over everything (inventing itself as a final vocabulary), or imagining that cognition is a matter only for human minds and human minds alone". Drawing from Haraway and Grosz's material semiotics illustrates that weaving practices are all important to the politics of inhabitation [...] to enliven understandings of the importance of non-human and human acts in the making of worlds (and the spatialities that are implied in those activities" (p.217)

vi The three forms-of-(care, repair, imagine) are tightly intertwined and conducive to one another. Care and repair are increasingly discussed in the same scholarship (Jackson, 2014; Mattern 2018; Graziano, and Trogal, 2019 to name but few). Millington (2019) argues that "Repair can also be a care practice, especially if we understand the infrastructures that surround us to be interlinked in complex, intimate ways with broader dynamics of social reproduction."
} 